\title{
Echinococcus granulosus sensu lato and Taenia bydatigena in pig in southern Brazil
}

\author{
Echinococcus granulosus sensu lato e Taenia hydatigena em suínos no sul do Brasil
}

Danieli Urach Monteiro' ${ }^{1}$; Sônia de Avila Botton ${ }^{1}$; Alexandre Alberto Tonin ${ }^{1}$; Karen Luisa Haag²;

Germano Musskopf ${ }^{3}$; Maria Isabel Azevedo ${ }^{1}$; Carla Weiblen ${ }^{1}$; Tatiana Correa Ribeiro ${ }^{1}$; Mário Luiz de la Rue ${ }^{1 *}$

\begin{abstract}
${ }^{1}$ Departamento de Microbiologia e Parasitologia, Universidade Federal de Santa Maria - UFSM, Santa Maria, RS, Brazil
${ }^{2}$ Departamento de Genética, Universidade Federal do Rio Grande do Sul - UFRGS, Porto Alegre, RS, Brazil

${ }^{3}$ Ministério da Agricultura Pecuária e Abastecimento, Brasília, DF, Brazil
\end{abstract}

Received November 5, 2014

Accepted December 10, 2014

\begin{abstract}
This study aimed to identify the parasitical etiologic agents of visceral cysts in pigs from the central/northern region of Rio Grande do Sul State, Brazil. Fifty-eight cysts were found in livers during veterinary inspection of swine slaughtered from January 2008 to 2012. Collected samples were submitted to macroscopic and molecular analyzes. Polymerase chain reaction (PCR), DNA sequencing and BLAST alignment of sequences was used to molecular characterization of the samples. By PCR 10.3\% (6/58) of tested samples were positive for Echinococcus granulosus sensu lato and 56.9\% (33/58) for Cysticercus tenuicollis. In this study, it was verified the occurrence of larval forms of E. granulosus sensu lato and Taenia hydatigena in pig herds from the central/northern region of Rio Grande do Sul State. The presence of both parasites is relevant due to the economic losses for the meat industry. Additionally, E. granulosus sensu lato has zoonotic importance and may be infecting pig herds in southern Brazil.
\end{abstract}

Keywords: Echinococcus granulosus sensu lato, Taenia hydatigena, pigs, Brazil.

\section{Resumo}

Neste estudo, buscou-se identificar os agentes etiológicos de origem parasitária em cistos nas vísceras de suínos oriundos sa região centro/norte do sEstado do Rio Grande do Sul, Brasil. Cinquenta e oito cistos foram encontrados durante a inspeção veterinária em fígados de suínos abatidos entre janeiro de 2008 a 2012. As amostras foram submetidas às análises macroscópicas e moleculares. Reação em cadeia da polimerase (PCR), sequenciamento de DNA e alinhamento das sequências no BLAST (bases de dados do GenBank) foram utilizados na caracterização molecular das amostras. Das amostras analisadas, 10,3\% (6/58) foram positivas para Echinococcus granulosus sensu lato e 56,9\% (33/58) para Cysticercus tenuicollis. Evidenciou-se a ocorrência de larvas de E. granulosus sensu lato e Taenia hydatigena em rebanhos suínos na região centro/norte do RS. A presença de ambos os agentes é relevante devido às perdas econômicas para a indústria de carnes. Além disso, destaca-se que E. granulosus sensu lato possui importância zoonótica e pode contaminar os rebanhos suínos no sul do Brasil.

Palavras-chave: Echinococcus granulosus sensu lato, Taenia hydatigena, suínos, Brasil.

\section{Introduction}

Cystic echinococcosis is a zoonotic disease caused by the genus Echinococcus (Cestoda: Taeniidae). In Brazil, the disease is endemic in the southern part of the state of Rio Grande do Sul, causing infection in humans and animals and leading to high economic losses to livestock, as well as public health problems

${ }^{*}$ Corresponding author: Mário Luiz de la Rue. Departamento de

Microbiologia e Parasitologia, Campus Universitário, Universidade Federal de Santa Maria - UFSM, Avenida Roraima, 1000, Prédio 20, Sala 4226, CEP 97105-970, Santa Maria, RS, Brasil.

e-mail: mldelarue@hotmail.com
(ROMIG, 2003; GROSSO et al., 2012; DE LA RUE, 2008). Pigs are considered to be important intermediate hosts of the larval stage of the genus Echinococcus (hydatid cysts), thereby helping to maintain the parasite cycle on farms and consequently infecting dogs. Dogs are then able to disperse the parasite eggs and this can be considered to present a risk of human infection (KAMENETZKY et al., 2002; DE LA RUE, 2008).

Another cestode commonly present in RS is Taenia hydatigena, which although not infective for humans, also causes damage to the meat industry. Its larval stage is called Cysticercus tenuicollis, and it is very similar to the hydatid cysts developed by Echinococcus granulosus (CABRERA et al., 1995). Similar to E. granulosus sensu 
lato, T. hydatigena also has the same intermediate hosts including: sheep, cattle and pigs. When these animals are slaughtered in abattoirs with sanitary inspection, they are subjected to rigorous examination in order to identify any possible alterations in the carcasses and presence of cysts in viscera. However, the method to identify cystic parasite is based on visual (macroscopic) observation in tissues, mainly in the liver and lungs of intermediate host species (BRASIL, 1999). Despite that, the differential diagnostic for these parasitosis is very important since these infections generate economic losses; however, cystic echinococcosis is a problem for public health.

The aim of the present study was to identify parasitological agents in visceral cysts collected from swine slaughtered under veterinarian inspection located in central/northern regions of Rio Grande do Sul State, Brazil.

\section{Materials and Methods}

In this study pigs viscera with different cystic lesions were collected by veterinarians from slaughterhouses located in the central/northern regions of Rio Grande do Sul State. A total of 3,101,992 pigs were slaughtered between January/2008 and January/2012, been all of them inspected by the veterinarian federal inspection service of the Brazilian Ministry of Agriculture. Among these inspected animals, 58 cysts presented morphology compatible with hydatid cysts were found and examined. Each of the samples came from a different animal and was processed separately. Total DNA was isolated and purified using a QIAmp DNA mini-kit (Qiagen, USA), in accordance with the manufacturer's instructions. DNA from an adult E. granulosus sensu lato, obtained from an infected dog, was used as a positive control and ultrapure water was used as a negative control. A fragment of the cytochrome c oxidase subunit I (Cox I) gene of E. granulosus sensu lato was amplified by PCR assay as described by Bowles et al. (1992). Amplification was performed using a PTC 100 thermocycler (MJ Research, Inc., USA). To detect the band pattern, electrophoresis on 1\% agarose gel was carried out with ethidium bromide staining. The results were viewed under UV light. PCR-positive products for E. granulosus sensu lato were purified using the PureLink kit (Invitrogen, USA) been DNA sequencing performed in an automated sequencer (MegaBACE500, Japan) using the DYEnamic ET kit (Amersham, UK ) and the same PCR primers. The similarity of the DNA sequencing samples was ascertained by means of the BLAST program (Basic Local Alignment Search Tool; http://www.ncbi.nlm.nih.gov/Blast.cgi).

\section{Results}

Macroscopic examination of collected cysts showed general features, such as small and unmarked lesions with bullous format, filled with liquid. However, identification of the parasite was not possible. Protoscoleces were not observed by microscopical examination in any of the examined samples. Comparison of the results obtained from DNA sequencing using the GenBank database (http://www.ncbi.nlm.nih.gov/genbank) confirmed E. granulosus sensu lato in $10.3 \%$ samples (6/58), while Cysticercus tenuicollis was detected in 56.9\% (33/58). In 32.8\% of the samples (19/58) there was no amplification by PCR been these samples submitted to histological examination. It was verified the presence of hypertrophic sub-capsular muscle layer or sub-capsular simple cyst in the examined samples. In these samples, cysts did not have parasitic origin, or there was no sufficient amount of DNA for accurate sample identification.

\section{Discussion}

The low occurrence of E. granulosus sensu lato detected in this study can be explained by the rearing system used for pigs in central/northern region of Rio Grande do Sul State, Brazil. The animals are kept in an intensive farming system with restricted access to contamination due to limited contact with infected dogs. Although pigs become infected more rarely, they also seem to be well suited for developing fertile cysts (BRUZINSKAITE et al., 2009). Cystic lesions of varying shapes and sizes, corresponding to hydatid cysts in the viscera of cattle and sheep, have been reported by some authors in Rio Grande do Sul State, generally in the southern part of the state where farming is an important economic activity, which probably facilitates the access of dogs to these intermediate hosts (DE LA RUE et al., 2008; BALBINOTTI et al., 2012). However, the central/northern region of this state has not been targeted in investigations on cystic echinococcosis over recent years. Pigs have been reported to be intermediate hosts of Echinococcus spp. in countries like Argentina, Mexico and Peru (SANCHEZ et al., 2012; KAMENETZKY et al., 2002; VILLALOBOS et al., 2007). The occurrence of cystic echinococcosis cases in the studied area suggests that there is a practice of feeding dogs with contaminated viscera from pigs, sheep and/or cattle, which consequently perpetuates the life cycle of this parasite on studied regions. The contamination of pigs is probably related to their diet, since the food could be contaminated with eggs of the parasite. However, Torgerson et al. (1995) have already reported the possibility that Echinococcus spp. eggs may be transported by mechanical means, such as by birds or even by the wind, thus allowing the contamination of large areas. In Brazil, notification of findings of cystic echinococcosis in intermediate hosts slaughtered under supervision by the veterinarian federal inspection service is mandatory, thus making it possible to generate official data on cyst occurrence in livestock animals (BRASIL, 1999). However, macroscopic analysis does not provide accurate and correct identification of these lesions in intermediate hosts and this probably leads to misdiagnosis of parasitic diseases. This hypothesis is strongly supported by the fact that the cysts of E. granulosus sensu lato have no particular morphology, thus making it difficult to perform differential diagnoses, especially with $T$. hydatigena, and leading to mismatch with the official data from slaughterhouses under supervision by the veterinarian inspection (SLAIS \& VANĚK, 1980).

This study also revealed the occurrence of $T$. hydatigena larval stages in $56.9 \%$ of analyzed samples. The high number of C. tenuicollis in slaughtered pigs leads to discarding of the viscera, thereby causing high economic losses for the meat industry. For this reason, differential diagnosis is a very important tool for 
avoiding disposal of organs contaminated by $C$. tenuicollis, since it does not represent a risk to public health.

In $32.8 \%$ of analyzed cysts a parasitological origin was not identified using the universal primers to amplify a fragment of Cox I gene. Possibly, the total DNA obtained in these samples was insufficient to be detected by PCR. Furthermore, the macroscopic and histological analyses did not allowed to identify the presence of any protoscoleces and parasitological agent.

However, the presence of E. granulosus sensu lato in pigs is a relevant data due lacking information about the real contamination of swine by Echinococcus spp. in Brazil. Also, this parasite represents an economic problem in meat industry, as well as a great risk to the animal and public health.

\section{References}

Balbinotti H, Santos GB, Badaraco J, Arend AC, Graichen DAS, Haag $\mathrm{KL}$, et al. Echinococcus ortleppi (G5) and Echinococcus granulosus sensu stricto (G1) loads in cattle from Southern Brazil. Vet Parasitol 2012; 188(3-4): 255-260. http://dx.doi.org/10.1016/j.vetpar.2012.04.007. PMid:22571833

Bowles J, Blair D, McManus DP. Genetic variants within the genus Echinococcus identified by mitochondrial DNA sequencing. Mol Biochem Parasitol 1992; 54(2): 165-173. http://dx.doi.org/10.1016/01666851(92)90109-W. PMid:1435857

Brasil. Regulamento da inspeção industrial e sanitária dos produtos de origem animal. Decreto $n^{\circ}$ 39.688. Porto Alegre: 30 Agosto 1999. [cited 2014 Maio 23] Available from: http://www2.agricultura.rs.gov.br/uploads/126755739 81178912758Decreto_39688_99_Regulamento_Inspecao_CISPOA.pdf.

Bruzinskaite R, Sarkūnas M, Torgerson PR, Mathis A, Deplazes P. Echinococcosis in pigs and intestinal infection with Echinococcus spp. in dogs in southwestern Lithuania. Vet Parasitol 2009; 160(3-4): 237241. http://dx.doi.org/10.1016/j.vetpar.2008.11.011. PMid:19111990
Cabrera PA, Haran G, Benavidez U, Valledor S, Perera G, Lloyd S, et al. Transmission dynamics of Echinococcus granulosus, Taenia hydatigena and Taenia ovis in sheep in Uruguay. Int J Parasitol 1995; 25(7): 807-813. http://dx.doi.org/10.1016/0020-7519(94)00209-7. PMid:7558566

De la Rue ML. Cystic echinococcosis in southern Brazil. Rev Inst Med Trop Sao Paulo 2008; 50(1): 53-56. http://dx.doi.org/10.1590/S003646652008000100012. PMid:18327489

Grosso G, Gruttadauria S, Biondi A, Marventano S, Mistretta A. Worldwide epidemiology of liver hydatidosis including the Mediterranean area. World J Gastroenterol 2012; 18(13): 1425-1437. http://dx.doi.org/10.3748/wjg. v18.i13.1425. PMid:22509074

Kamenetzky L, Gutierrez AM, Canova SG, Haag KL, Guarnera EA, Parra A, et al. Several strains of Echinococcus granulosus infect livestock and humans in Argentina. Infect Genet Evol 2002; 2(2): 129-136. http:// dx.doi.org/10.1016/S1567-1348(02)00131-4. PMid:12797989

Romig T. Epidemiology of echinococcosis. Langenbecks Arch Surg 2003; 388(4): 209-217. http://dx.doi.org/10.1007/s00423-003-0413-3. PMid:12937989

Sánchez E, Cáceres O, Náquira C, Miranda E, Samudio F, Fernandes O. Echinococcus granulosus genotypes circulating in alpacas (Lama pacos) and pigs (Sus scrofa) from an endemic region in Peru. Mem Inst Oswaldo Cruz 2012; 107(2): 275-278. http://dx.doi.org/10.1590/S007402762012000200019. PMid:22415269

Slais J, Van囚k M. Differential diagnosis of cysticerci of Taenia hydatigena and hydatids of Echinococcus granulosus. Angew Parasitol 1980; 21(1): 16-20. PMid:7377625.

Torgerson PR, Pilkington J, Gulland FMD, Gemmell MA. Further evidence for the long distance dispersal of taeniid eggs. Int J Parasitol 1995; 25(2): 265-267. http://dx.doi.org/10.1016/0020-7519(94)000945. PMid:7622335

Villalobos N, González LM, Morales J, Aluja AS, Jiménez MI, Blanco MA, et al. Molecular identification of Echinococcus granulosus genotypes (G1 and G7) isolated from pigs in Mexico. Vet Parasitol 2007; 147(1-2): 185-189. http://dx.doi.org/10.1016/j.vetpar.2007.03.021. PMid:17467177 